\title{
TRANSITIVITY ANALYSIS OF NAHUM SITUMORANG'S TRADITIONAL SONG LYRICS
}

\author{
Arsen Nahum Pasaribu \\ English Literature Department Faculty of Languages and Arts \\ University of HKBP Nommensen Medan, Indonesia \\ arsen.pasaribu@uhn.ac.id
}

\begin{abstract}
Culture is manifested in many ways. Traditional song is one of the cultural manifestations representing a social life of an ethnic group. Culture recognition, such as understanding traditional song meanings, is believed to preserve cultural heritage. Accordingly, this study aimed at analyzing transitivity patterns used in 10 traditional song lyrics written by a famous Toba Batak traditional song writer, Nahum Situmorang, to find out the experiential meanings realized in his masterpiece. The method of the study is a quantitative descriptive. Transitivity analysis put forwarded by Halliday [1] under Systemic Functional Grammar served as the tool of data analysis. The result of the study yields two major findings as follows: 1). All of the six process types can be found in Nahum Situmorang's traditional song lyrics, 2). Material process and mental process are the most frequently occurred process types in the traditional song lyrics. This indicates that his song lyrics are overwhelmed by emotional description of social phenomena.
\end{abstract}

Keywords - culture, Nahum Situmorang, traditional song lyrics, transitivity, process, Toba Batak

\section{Introduction}

The study of transitivity on the text analysis has increased in numbers for the last decade. This indicates that many scholars have shown great interests in transitivity analysis on social phenomena expressed in various texts. In media discourse, Zhao Yuqiong [2] analyzed the political speech of David Cameron using transitivity to find out the distribution and functions of transitivity processes and the main participants in the speech. Quite similarly, Zhang [3] examined the political debate between Hillary Clinton and Donald Trump using transitivity to discover the distribution of six processes used by the two presidential candidates. In the area of literary work, Nguyen [4] investigated the language choice by a narrative writer to identify and explain how the main character's personality portrayed and presented in a story using transitivity analysis. Likewise, the application of transitivity was also used by Wahyuni et.al. [5] to find out the linguistic choice by the students when writing the memoirs. Similarly, Opara [6] explored the language choice in depicting the characters in narrative discourse. Adzar and Yadzchi (7) analyzed transitivity pattern in a short story "Clay" by James Joyce in order to prove the literary critique on "Maria" as a symbol of virgin Marry in the story. Based on the fact, the study of text using transitivity system still dominantly focuses on the media discourse - political debate, campaign, and speech and literary text - novels, short stories, poems. The studies using transitivity analysis on song lyrics investigating the verbal choice by the song writers to describe social phenomena are relatively few. Therefore, the attempt to 
examine the semantic meaning of song lyrics through transitivity analysis on types of the process in especially traditional songs is the focus of the study.

Traditional songs as the oral tradition are viewed not only as the entertaining arts, but also as the oral text containing the message of the writers as explained by Peake [8]. In fact, as Griffee [9] explained that song Interpretation can be as the historical evidence of social and cultural lives depicted in the lyrics. The current study on song lyric was completed by Zahoor and Jangjua [10] to investigate a popular song entitle "I am Malala" using transitivity system. This study was still limited to the number of data, only using a single song lyric.

Therefore, this study focused on the social phenomena, especially in Toba Batak ethnic group, pictured in the traditional song lyrics. It is to discover how the song writer realized the meaning in his song lyrics using transitivity system by analyzing the process of each clause of the song lyrics.

The choice of song lyrics written in Toba Batak language by Nahum Situmorang is based on two reasons: firstly, Nahum Situmorang was a famous, productive and creative Toba Batak song writer. More than one hundred of his song lyrics in Toba Batak language have been released as the sufficient data for this study. Secondly, his song lyrics can represent the social life and cultural events of Toba Batak in the last decades.

\section{Review Of Literature}

\section{a. Systemic Functional Grammar}

Systemic functional grammar is the grammar system developed by Halliday [1] attempting to describe language in actual use and focusing on text and their context as in Gerot and Wignell [11]. Systemic functional grammar views language as a source of meaning making in understanding how text works.

Systemic functional grammar is divided into three categories by Halliday [1] and as in Bloor and Bloor [12], which is termed as metafunction: ideational metafunction, interpersonal metafunction, and textual metafunction.

\section{Ideational metafunction}

Ideational function is concerned with how language is use to organize, understand, and express our perceptions of the world and of our consciousness. Ideational function is divided into experiential and logical metafunctions. Experiential metafunction is concerned with contents or ideas. Logical metafunction is concerned with the relationship of the ideas.

2. Interpersonal metafunction

Interpersonal metafunction is concerned with interchanging information in social interaction. It enables us to participate in communicative acts with other people, to take roles, to express and understand feeling, attitude, and judgements as in Bloor \& Bloor [12]. 


\section{Textual metafunction}

Textual metafunction is related to the function of language to organize the events or experiences in the spoken or written forms.

b. Transitivity

Transitivity is a part of ideational function of the clause. It is the foundation of the semantic organization of idea presentation, Halliday [1]. According to Beard [13] transitivity is concerned with the actions that take place, the participants that are involved in the actions, and the circumstance when, where, how, and why the actions occur. In the similar vein, Iwamoto (2008) emphasizes the basic function of transitivity is to explore "who or what does what to whom or to what". Transitivity is divided into three main parts: the process (the action), which is realized by verb phrase, the participant(s) (the doer), carrying out or being affected by the process and usually realized by noun phrase, and finally the circumstance (s) (the situation), forming the adjunct component of the clause generally expressed by the prepositional and adverbial phrases as stated by Simpson [14].

\section{c. Process and Participants}

Process is the center of a clause that involves the participants. Thus, the process and participants are a unity, meaning that the actions will not happen without participants. In the transitivity system, there are six types of process and the participants involved in the process that are termed according to each type of the process. The following table shows the types of process and the participants involved in the process.

Table 1: Process types, their meanings, and key participants

\begin{tabular}{|l|l|l|}
\hline \multicolumn{1}{|c|}{ Process types } & \multicolumn{1}{|c|}{ Category meaning } & Participants \\
\hline $\begin{array}{l}\text { Material: } \\
\text { Action, event }\end{array}$ & $\begin{array}{l}\text { Doing, happening, e.g. } \\
\text { kick, write, watch, etc. }\end{array}$ & Actor, goal \\
\hline Behavioral & $\begin{array}{l}\text { Behaving, e.g. smile, } \\
\text { laugh, etc. }\end{array}$ & Behaver \\
\hline $\begin{array}{l}\text { Mental: } \\
\text { Perception, affection, } \\
\text { cognition }\end{array}$ & $\begin{array}{l}\text { Sensing, seeing, } \\
\text { feeling, thinking, e.g. } \\
\text { see, hear, feel, know, } \\
\text { etc. }\end{array}$ & $\begin{array}{l}\text { Sensor, } \\
\text { phenomenon }\end{array}$ \\
\hline Verbal & $\begin{array}{l}\text { Saying, e.g. tell, say, } \\
\text { warn, ask }\end{array}$ & Verbiage, target \\
\hline $\begin{array}{l}\text { Relational: } \\
\text { Attribution, } \\
\text { identification, } \\
\text { possession }\end{array}$ & $\begin{array}{l}\text { identifying, e.g. be, become } \\
\text { have, become }\end{array}$ & $\begin{array}{l}\text { Carrier- } \\
\text { attribute, token- } \\
\text { value, } \\
\text { possessor- } \\
\text { possessed }\end{array}$ \\
\hline Existential & $\begin{array}{l}\text { Existing, e.g. there +to } \\
\text { be }\end{array}$ & Existence \\
\hline
\end{tabular}

(Modified types of process by Halliday, 1994: 143) 
Table 1 shows the types of the process and the participants involved in the process. Material process represents physical and concrete action in category of "happening or doing". The participants are term as the actor (the doer of the events) and the goal (the object of the action). Behavioral process denotes the outer realization of inner activities, the representation of consciousness and physiological state, such as smile, laugh, etc. This process only involves a single participant termed as "behaver". Mental process describes "perception, cognition, and affection or feeling". The participants are termed as a "senser" that has the perception, cognition, and affection, and "phenomenon" - what is perceived, thought or felt by the sensor. Relational process refers to process of "being". It is divided into three main types: attribution, possession and identification. Attributive category takes two participants: a carrier and an attribute. The identifying category also has two participants, termed as token-value, and possession is represented by two participants - possessor and possessed. Verbal process represents the act of "saying". It consists of participants: "sayer", the one who speaks, and "target" or "verbiage", what is said. The last process is existential. It asserts something "exist" by using the pseudo participant "there" that is termed as "existent". The following table shows the examples of different process types.

Table 2: The examples of different process types

\begin{tabular}{|c|c|c|}
\hline $\begin{array}{c}\text { Process } \\
\text { Type }\end{array}$ & Examples & Explanation \\
\hline Material & $\begin{array}{l}\text { Felicia is } \\
\text { writing a letter }\end{array}$ & $\begin{array}{l}\text { Process: writing } \\
\text { Participants: "Felicia" as } \\
\text { the actor and "a letter" as } \\
\text { the goal }\end{array}$ \\
\hline Mental & $\begin{array}{l}\text { I understand } \\
\text { your condition }\end{array}$ & $\begin{array}{l}\text { Process: understand } \\
\text { Participants: "I" as the } \\
\text { senser, "your condition" } \\
\text { as phenomenon }\end{array}$ \\
\hline Relational & $\begin{array}{l}\text { She is a good } \\
\text { teacher }\end{array}$ & $\begin{array}{l}\text { Process: be } \\
\text { Participants: "She" as the } \\
\text { carrier and "a good } \\
\text { teacher" as the attributive }\end{array}$ \\
\hline Behavioral & $\begin{array}{l}\text { He laughed } \\
\text { loudly }\end{array}$ & $\begin{array}{l}\text { Process: smiled } \\
\text { Participants: "He" as the } \\
\text { behaver. }\end{array}$ \\
\hline Verbal & $\begin{array}{l}\text { Rina told me } \\
\text { that I passed } \\
\text { the exam }\end{array}$ & $\begin{array}{l}\text { Process: told } \\
\text { Participants: "Rina" as } \\
\text { the sayer, and "me" as } \\
\text { the target, " I have } \\
\text { passed the exam" as the } \\
\text { verbiage }\end{array}$ \\
\hline Existential & $\begin{array}{l}\text { There is a car } \\
\text { in the garage }\end{array}$ & $\begin{array}{l}\text { Process: There }+ \text { is } \\
\text { Participant: "a car" as the } \\
\text { existent. }\end{array}$ \\
\hline
\end{tabular}




\section{Method}

This study is a quantitative descriptive. That is the research method that shows numbers, percentage, and charts as the presentation of data analysis results. Systemic Functional Grammar, specifically transitivity system as a part of experiential metafunction, is used as the theoretical foundation and analytical tool to investigate the semantic meaning in Nahum Situmorang's song lyrics. The analysis is focused on the types of process in the song lyrics. Ten song lyrics, which are written in Toba Batak Language, were chosen randomly from 100 song lyrics written by Nahum Situmorang. The ten titles of the songs chosen are: (1) Alusi Au (Listen to Me), (2) Dijou Au Mulak tu Rura Silindung (I am Called Back to Silindung Valley), (3) O Tao Toba (Oh Lake Toba), (4) Pulo Samosir (Samosir Island), (5) Ketabo Ketabo (Let's go), (6) Sai Tudia Ho Marhuta (Where will you settle down), (7) Na Sonang do Hita na Dua (We are a happy couple), (8) Sai Gabe ma Ho (Wish you are happy), (9) Malala Rohangki (My Heart is broken), (10) Anakhon hi do Hamoraon di Au (My Children are My Wealth).

\section{Findings And Disscussion}

The finding shows that there are 182 processes found in the 10 selected song lyrics. The most dominant type of process is material process, and the least occurrence is existential process. The following table shows the type of process found in the each song lyrics.

Table 3: Types of process in the song lyrics

\begin{tabular}{|c|c|c|c|c|c|c|c|}
\hline \multirow{2}{*}{$\begin{array}{l}\mathbf{N} \\
\mathbf{0}\end{array}$} & \multirow{2}{*}{$\begin{array}{c}\text { Song } \\
\text { Lyrics } \\
\end{array}$} & \multicolumn{6}{|c|}{ Types of Process } \\
\hline & & Mat & Men & Rel & Beh & Verb & Exist \\
\hline 1 & Alusia Au & 11 & 4 & 7 & 2 & - & 1 \\
\hline 2 & $\begin{array}{l}\text { Dijou au } \\
\text { Mulak tu } \\
\text { Rura } \\
\text { Silindung }\end{array}$ & 14 & 12 & 2 & 1 & - & - \\
\hline 3 & $\begin{array}{ll}\text { O } & \text { Tao } \\
\text { Toba } & \\
\end{array}$ & 2 & 2 & 8 & 1 & - & - \\
\hline 4 & $\begin{array}{l}\text { Pulo } \\
\text { Samosir }\end{array}$ & 11 & 8 & 5 & 5 & - & 1 \\
\hline 5 & $\begin{array}{l}\text { Ketabo } \\
\text { Ketabo }\end{array}$ & 13 & 1 & 6 & - & 3 & - \\
\hline 6 & $\begin{array}{l}\text { Sai Tudia } \\
\text { Ho } \\
\text { Marhuta }\end{array}$ & 3 & 4 & 1 & 1 & - & - \\
\hline 7 & $\begin{array}{l}\text { Na Sonang } \\
\text { do Hita na } \\
\text { Dua }\end{array}$ & - & 5 & - & 1 & - & - \\
\hline 8 & $\begin{array}{l}\text { Sai Gabe } \\
\text { ma Ho }\end{array}$ & 6 & 9 & 1 & 1 & 1 & - \\
\hline 9 & $\begin{array}{l}\text { Malala } \\
\text { Rohangki }\end{array}$ & 2 & 4 & 6 & - & - & - \\
\hline 10 & $\begin{array}{l}\text { Anakhon } \\
\text { hi do } \\
\text { Hamoran } \\
\text { di Au }\end{array}$ & 8 & 8 & - & 1 & - & - \\
\hline & Total & 70 & 57 & 36 & 13 & 4 & 2 \\
\hline
\end{tabular}


Table 2 shows that the song lyrics of "Alusi Au", "Dijou au Mulak tu Rura Silindung", "Pulo Samosir", and "Ketabo Ketabo" are dominantly represented by material process. Mental process is dominantly occurred in "Sai Gabe ma Ho" song lyric. Relational process is mainly found in "O Tao Toba" and "Malala Rohangki" song lyrics. Existential process is the least occurrence among the processes. It appears only in "Alusi Au" and "Pulo Samosir". Likewise existential process, verbal process is merely found in the song lyrics of "Ketabo Ketabo" and "Sai Gabe ma Ho". Of all the processes, Mental process is the only one that occurred in all of the song lyrics.

As explained that transitivity is concerned with the types of action and the participants involved in the action, this section seek to discuss the semantic interpretation of the finding above. The song lyrics "Alusi Au" (listen to me) is dominantly realized in material process, 14 out of 25 process occurrences. It indicates that the song writer as the actor really expected the goal to listen his explanation. This is similar to "Dijou do Au Mulak tu Rura Silindung" (I am Called Back to Silindung Valey), it consists of 29 processes that is mostly occurred in material process, 14 times and then followed by mental process, slightly lower than that of material process, namely 12 occurrences. This result shows that the song reflected that the Rura Silindung Valley (as the actor) called the writer (as the goal) to come back. This song lyric also expressed the writer's (as the senser) feeling toward the beauty of the valley.

The result in "Dijou do Au Mulak tu Rura Silindung" lyric is similar to "Pulo Samosir" (Samosir Island) lyric. "Pulo Samosir" lyric mainly consists of material process (11), mental process (8), behavioral (5), relational (5), existential (1). This finding reveal that the song lyric contains the description of the Toba Batak People that reside in Pulo Samosir. It also explored the writer's (senser) feeling toward the island.

The song lyric "Ketabo Ketabo" also mostly contains material process (13) and relational process (6). The song lyric describe the writer's (actor) invitation to visit a place (Sidimpuan city, located in southern part of North Sumatra Province. The place (carrier/token) is depicted as the famous for its view and friendly people.

The song lyric "Anakhon hi do Hamoran di Au" dominantly consists of equal number of material process and mental process, each is represented by 8 occurrences. This result shows that the song writer (as the actor) sought to explain that his hard work is only meant to support his children education. He (as the senser) love his children as precious wealth).

Relational process as the most dominant process was found in the song lyrics "O Tao Toba" (Oh, Lake Toba) and "Malala Rohangki". In "O Tao Toba", the process comprises of relational (8), material (2), mental (2), and behavioral (1). This text explains the beauty of Toba Lake (as the carrier/token). In "Malala Rohangki", the process constitutes relational (6), mental (4), and material (2). This song lyric explains the writer's broken heart (carrier/token).

This study has shown that transitivity system can be utilized to analyze traditional song lyrics to uncover the writer's ideas. The language choice by the song writer is meant to find the proper ways to express the writer's intention through the song lyrics, as confirmed by Nguyen [4], Wahyuni, et.al [5], Opara [6]. 


\section{Conclusion}

This study is focused on the analysis of Nahum Situmorang's traditional song lyrics using transitivity system to find out linguistic choice by the song writer to express his intention and messages to the song listeners. The six types of the processes were found in 10 song lyrics. The most dominant process is material, which is almost half of the whole process, and followed by mental process. The results can be used as the guidance to interpret the intended meaning of the song writer.

\section{REFERENCE}

[1] M.A.K. Halliday, "Introduction to functional grammar", (2nd Ed.), London: Arnold, 1999.

[2] L.F. Zhao Yuqiong, "Transitivity analysis of David Cameron's speech in retaining Scotland". International Journal of Language and Linguistics, 2018, vol. 6, No.3, pp. 70-79

[3] Y. Zhang, “Transitivity analysis of Hillary Clinton,s and Donald Trump's first television debate". International Journal of Applied Linguistics and English Literature, 2017, Vol. 6, Issue: 7, pp. 65-72

[4] H.T. Nguyen, "Transitivity analysis of "Heroic Mother" by Hoa Pham". International Journal of Linguistics, Vol. 2, No. 4, 2012, pp.85-100

[5] R. Wahyuni, H. Hamjah, , D. Wahyuni, (2019). "An analysis of transitivity system in memoirs written by EFL students". E-Journal of English Journal of English Language \& Literature, Vol. 8, No. 1, 2019, pp. 149- 157

[6] S. Opara, "Transitivity system in selected narrative discourse". International Journal of Arts and Commerce, vol.1 no. 7, 2012, pp. 109-121.

[7] A. S. Azar, and N.S. Yadzchi, "A stylistic analysis of "Maria” in "Clay": the character in James Joyce's short story". Journal of Basic and Applied Scientific Research, 2, 2, 2012, pp. 1050-1-55.

[8] L.E. Peake (1980). "Song: The New Grove Dictionary of Music and Musicians", sixth edition, 20 vols., edited by Stanley Sadie, Vol. 17: 510-523. London: Macmillan Publishers; New York: Grove's Dictionaries, 1980.

[9] D.T. Griffee, (1992). "Songs in action". The New Grove Dictionary of Music and Musicians, London: Macmillan Publishers; New York: Grove's Dictionaries, 1992

[10] M. Zahoor, and F. Jangjua, "Character construction in tributive songs: Transitivity analysis of the song "I am Malala”. Trames, 20, ,2, 2016, 201-213.

[11] L. Gerot and W. Peter, "Making sense of functional grammar". Sydney: Tanya Stabbler, 1994

[12] T. Bloor and M. Bloor, "The functional analysis of English" (2nd Ed.). London: Arnold, 2004

[13] A. Beard, "The language of politics". London: Routledge, 2000

[14] P. Simpson, "Stylistics: a resource book for students". New York: Rouletge, 2004 